\title{
Külföldi egészségügyi ellátások az európai uniós és a magyar szabályok tükrében
}

\section{KRISTÓ KATALIN ${ }^{1}$ - BORBÁS SZILVIA ${ }^{2}$}

Az egységes belsö piac müködését biztositó egyik alapelv, a személyek szabad mozgása értelmében az uniós polgároknak lehetöségük van egy másik európai uniós tagállam területén letelepedni, munkát vállalni és tanulmányokat folytatni. Figyelemmel arra, hogy a szociális és társadalombiztositási rendszerek kialakitása és müködtetése a tagállamok kizárólagos hatáskörébe tartozik, az uniós polgárok jogainak érvényesitése és így a személyek szabad mozgásának zökkenömentes müködése érdekében az Európai Unió feladata a különbözó tagállami szociális biztonsági rendszerek közötti koordináció érvényesitése is. Ezen koordinációs szabályozásnak köszönhető a jelen tanulmány tárgyát képezö lehetőség is: az uniós polgároknak joguk van más tagállam területén egészségügyi szolgáltatást igénybe venni, a járulékfizetés helye szerinti ország társadalombiztositásának terhére. A tanulmány ismerteti a szociális biztonsági rendszerek koordinációjának uniós szabályozását, különös figyelemmel az egészségügyi ellátások külföldön történö igénybevételére, valamint bemutatja az uniós elöírások mentén kialakitott magyar szabályozást és gyakorlatot.

Kulcsszavak: tervezett és nem tervezett egészségügyi ellátások, szociális biztonsági koordináció, uniós polgárok szociális jogai, társadalombiztosítás, brexit

\section{Foreign Medical Treatment in the Light of European Union and Hungarian Rules}

The free movement of persons is one of the fundamental principles of the functioning single market, which allows EU citizens to settle, work and study in another EU country. Given that establishing and operating social and social security systems are within the exclusive competence of the Member States, the European Union is responsible for ensuring coordination between the different social security systems of the Member States in order to guarantee the rights of EU citizens and thus the smooth functioning of the free

1 Egyetemi docens, Nemzeti Közszolgálati Egyetem Államtudományi és Nemzetközi Tanulmányok Kar Lőrincz Lajos Közigazgatási Jogi Tanszék, e-mail: kristo.katalin@uni-nke.hu

2 A Nemzeti Közszolgálati Egyetem Államtudományi és Nemzetközi Tanulmányok Kar államtudományi mesterképzési szakán végzett hallgató. 
movement of persons. This regulation also provides for the topic of this study: EU citizens having the right to receive health care services in another Member State at the expense of the social security system of the country where they pay contributions. The study presents EU regulations on the coordination of social security schemes, with special regard to the use of health care in a foreign country, and describes the Hungarian legislation and practice being developed in line with EU regulations.

Keywords: planned and unplanned medical treatment, social security coordination, social rights of EU citizens, health insurance, Brexit

\section{A szociális biztonsági rendszerek koordinációja}

Tekintettel arra, hogy az 1950-es években az Európai Közösségek létrehozása elsősorban gazdasági célokat szolgált, az alapítókban nem merült fel az egységes európai szociálpolitika megteremtésének gondolata. Így a tagállamokban ma sem egységes szabályok alapján nyújtanak szociális juttatásokat. Mivel az egyes tagállamokban különböző fejlettségi szintű szociális rendszerek működnek, és szociálpolitikai téren az uniós jogharmonizáció csak korlátozottan érvényesül, ezért az Európai Unió máig is pusztán a nemzeti szabályok koordinálására törekszik. Teszi mindezt pedig annak érdekében, hogy megteremtse az Unión belül kezdetben a munkaerő szabad áramlását, később a személyek szabad mozgását.

A személyek szabad mozgásához szorosan kapcsolódik a szociális biztonsági rendszerek koordinációja, ${ }^{3}$ amely nélkül a szabad mozgás elve nem érvényesülhetne maradéktalanul, és amelynek célja, hogy azok a munkavállalók és hozzátartozóik ne szenvedjenek hátrányt, akik az Unió több tagállamában vállalnak munkát vagy telepednek le. A szociális biztonság a gazdasági tevékenységet folytató vagy korábban folytatott személyek bizonyos kockázatok elleni védelmét szolgáló ellátásokat jelenti. ${ }^{4} \mathrm{Az}$ ezzel kapcsolatos koordináció az alábbi ellátásokra vonatkozik:

- betegségi, anyasági és ennek megfelelő apasági ellátások;

- öregségi nyugdíj, előnyugdíj és rokkantnyugdíj;

- túlélő hozzátartozók ellátása, özvegyi és árvaellátás;

- munkanélküli segélyek;

- családi ellátások;

- munkahelyi baleset és foglalkozási megbetegedés címén nyújtott ellátások.

3 A témáról lásd bővebben Kristó Katalin: Szociálpolitika, szociális jog. Budapest, Nemzeti Közszolgálati Egyetem, 2014.

4 A szociális védelem másik területe a szociális segítségnyújtás, amely rászorultsági alapon nyújtott ellátásokat tartalmaz, és amelyek alapvetően a szegénységhez, nélkülözéshez kapcsolódnak. Az Európai Unióban csak a szociális biztonsági ellátásokat koordinálták, a szociális segélyezést nem. 
Az EU-s szociális biztonsági szabályozás hatálya kiterjed az Európai Gazdasági Térség tagállamaira és Svájcra. A vonatkozó szabályozást 2010. május 1-jétől korszerüsítették: az egyik legnagyobb újdonsága a szabályozásnak, hogy már nem csak a munkavállalók mobilitásának elősegítésére, hanem valamennyi polgár jogainak érvényesítésére összpontosítanak, függetlenül attól, hogy az érintettek dolgoznak-e vagy sem. A koordinációs mechanizmus jelenleg hatályos szabályozását a szociális biztonsági rendszerek koordinációjáról szóló 883/2004/EK rendelet (Rendelet) és az annak végrehajtására kiadott 987/2009/EK rendelet (Végrehajtási rendelet) tartalmazza. ${ }^{5}$

A szociális biztonsági rendszerek koordinációjának főbb alapelvei:

- az egyenlő bánásmód elve értelmében az uniós polgárok - állampolgárságuktól függetlenül - az egyes országok szociális biztonsági rendszereiben azonos elbírálás alá esnek. Ez mind a jogosultságok, mind pedig a kötelezettségek szempontjából érvényesülő szabály;

- az ellátások exportálhatóságának elve ${ }^{7}$ szerint az uniós polgárok megszerzett jogosultságaikat - bizonyos korlátozásokkal - megtarthatják más tagállamba költözés esetén is;

- az időszakok összeszámításának elve $e^{8}$ értelmében abban az esetben, ha egy tagállam valamely ellátásra való jogosultság megszerzését meghatározott szolgálati, biztosítási vagy tartózkodási idő meglétéhez köti, az adott ország illetékes hatóságának figyelembe kell vennie a másik tagállamokban megszerzett ilyen időszakokat is;

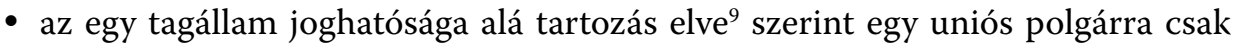
egy tagállam jogszabályai alkalmazandók. Ez a tagállam pedig a munkavégzés tagállama. Az alapelv célja, hogy kiküszöbölje az egyidejűleg fennálló többes biztosítási kötelezettséget, valamint azt a nemkívánatos helyzetet, amelyben valaki biztosítás nélkül marad. Azaz a koordinációs rendeletek szerint főszabályként a munkavállalás helye szerinti tagállam szociális biztonsági jogszabályai alkalmazandók.

A szociális biztonsági rendszerek koordinációjával tehát megvalósult a tagállamok egymástól különböző szociális ellátórendszereinek összehangolt működése, amely elengedhetetlen a személyek szabad áramlásának megvalósulásához. A koordinációs mechanizmus müködésében kiemelt jelentősége van a tagállamok különböző igazgatási szervezetei közötti kommunikációnak, az eljárásokhoz szükséges hatékony és egyben biztonságos információcserének. A Végrehajtási rendelet 4. cikke rendelkezik az adatcserék formátumáról és módjáról, amelynek (2) bekezdése alapján

5 A két elsődleges jogforrás mellett meghatározó jelentőségű az Európai Bíróság vonatkozó esetjoga, amely másodlagos jogforrásként szintén kötelező a tagállamokra nézve.

6 Rendelet 4-5. cikke.

7 Rendelet 7. cikke.

8 Rendelet 6. cikke.

9 Rendelet 11. cikk (1) bekezdése. 
az intézmények vagy a kapcsolattartási szervezetek közötti adattovábbítás elektronikus úton történik, közvetlenül vagy közvetve, a hozzáférési pontokon keresztül, egy közös, biztonságos kereten belül, amely alkalmas az adatok titkosságának és az adatcsere védelmének biztosítására. Ezen rendelkezés értelmében jött létre az EESSI rendszer (Electronic Exchange of Social Security Information), a szociális biztonságra vonatkozó információk elektronikus adatcseréjének megvalósítására, amely egy olyan informatikai rendszer, amelynek segítségével az EU minden tagállamának szociális biztonsági intézményei hatékonyan és gyorsan tudnak adatot cserélni és kommunikálni egymással. ${ }^{10}$

A központi EESSI-rendszert 2017 júliusára tették elérhetővé, amelyet követően két év állt a tagállamok rendelkezésére, hogy bevezessék az EESSI-t, és hogy szociális biztonsági intézményeiket csatlakoztassák a határokon átívelő elektronikus információcserét biztosító rendszerhez. Az EESSI-hez való csatlakozás érdekében vált szükségessé minden tagállam részéről - így magyar részről is - egy olyan informatikai rendszer fejlesztése, amely támogatja az EESSI rendszerén keresztül folytatott kommunikációt, biztosítja a kétoldalú szociális egyezmények keretein belüli papíralapú információcserét, kezeli a magyar Egészségbiztosítási Alap nyilvántartásai részére biztosított adatszolgáltatást, az azokból való adatlekérdezéseket. Így vezették be Magyarországon a HYDRA informatikai rendszert, amelyet 2020. november 1-je óta használnak az egészségbiztosítási pénztári feladatkörben eljáró igazgatási szervek. Ennek köszönhetően a végrehajtásban közreműködő, egészségbiztosítási feladatkörben eljáró igazgatási szervek közötti kapcsolattartás ma már elektronikus úton történik.

\section{Egészségügyi ellátások igénybevétele az Európai Unióban}

Az uniós koordinációs szabályozásnak köszönhető e tanulmány központi témáját képező lehetőség is: az uniós polgároknak joguk van más tagállam területén egészségügyi ellátást igénybe venni a járulékfizetés helye szerinti ország társadalombiztosításának terhére. A másik tagállam területén tervezett és nem tervezett módon vehető igénybe egészségügyi ellátás. A nem tervezett egészségügyi szolgáltatás igénybevétele az Európai Egészségbiztosítási Kártya (EU-kártya) birtokában egy viszonylag egyszerü útnak tekinthető, ${ }^{11}$ továbbá uniós elöírás, hogy el kell ismerni az uniós biztosítottak jogát arra, hogy EU-kártya nélkül is igénybe vehessenek engedélyhez nem kötött egészségügyi szolgáltatást más EU-tagállamban, amelynek a költségét belföldi

10 Hajdú József: A szociális jog elmúlt 20 évéről, különös tekintettel az Európai Unióra. In Miskolczi Bodnár Péter - Kun Attila - Boóc Ádám (szerk.): Gazdaság és jog. Húsz év jogalkotási fejleményei a civilisztika területén. Budapest, Károli Gáspár Református Egyetem Állam- és Jogtudományi Kar. 2019. 16.

11 Nem tervezett egészségügyi szolgáltatás igénybevétele olyan esetekben merül fel leginkább, amikor valamely tagállamban történő tartózkodás során váratlan baleset éri az uniós polgárt, vagy megbetegszik és halaszthatatlan orvosi ellátásra van szüksége. 
költségen meg kell téríteni a biztosítottak részére. ${ }^{12}$ Azonban a tervezett egészségügyi szolgáltatások egy részének igénybevételét ${ }^{13}$ összetett adminisztrációs, bizonyos esetekben engedélyezési folyamatnak szükséges megelőznie a járulékfizetés helye szerinti tagállam egészségbiztosítási szerve részéről. ${ }^{14}$

A tervezett és nem tervezett egészségügyi ellátások uniós kategóriái mellett szükséges megemlíteni egy további szabályozási csoportot is: azt az esetet, amikor az uniós polgár egészségügyi ellátást vesz igénybe az illetékes tagállamtól eltérő lakóhely szerinti tagállamban. Ebben az esetben az uniós polgárnak egy olyan igazolásra van szüksége, amely bizonyítja az egészségügyi ellátáshoz való jogot a lakóhely szerinti tagállamban, az illetékes tagállamon kívül is. Ez a speciális kategória elsősorban a határ menti munkavállalókat, valamint az áttelepült nyugdíjasokat és családtagjaikat érinti. E személyi kör tehát mindkét tagállamban, a munkavégzés, biztosítás (járulékfizetés) helye szerinti országban és az állandó lakóhely szerinti országban is igénybe vehet egészségügyi ellátást.

Fontos kiemelni, hogy az Európai Unió koordinációs szabályozása az egészségügyi ellátások egységes színvonalának garantálására nem alkalmas, hiszen a gyakorlatban nem létezik „európai szintü” ellátás; az egészségügyi szolgáltatások színvonalát mindig az adott ország teherbíró képessége fogja meghatározni.

\subsection{Az Európai Egészségbiztositási Kártya - nem tervezett egészségügyi ellátás igénybevétele}

Az EGT-tagállamokban, valamint Svájcban történő átmeneti tartózkodás során igénybe vehető, orvosilag szükséges ellátásokról ${ }^{15}$ a Rendelet 19. és 27 . cikke, valamint a Végrehajtási rendelet 25. cikke rendelkezik. A Rendelet 19. cikkének (1) bekezdése alapján az illetékes tagállamtól eltérő tagállamban tartózkodó biztosított személy és családtagjai jogosultak a tartózkodásuk alatt orvosi okokból szükségessé váló természetbeni ellátásokra, figyelembe véve az ellátások jellegét és a tartózkodás várható időtartamát. Ezeket az ellátásokat az illetékes intézmény nevében a tartózkodási hely szerinti közfinanszírozott intézmény nyújtja, az általa alkalmazott jogszabályok rendelkezései szerint, mintha az érintett személyek az említett jogszabályok szerint lennének biztosítva. A Végrehajtási rendelet 25. cikkének (1) bekezdése szerint az ellátás

12 Gellérné Lukács Éva: Egészségügyi szolgáltatások igénybevétele. In Smuk Péter (szerk.): Társadalmi fenntarthatóság. Budapest, Ludovika Egyetemi Kiadó, 2020. 1355.

13 Tervezett egészségügyi szolgáltatás igénybevételéről abban az esetben beszélhetünk, ha az uniós polgár kifejezetten azzal a céllal utazik egy másik, Európai Gazdasági Térséghez tartozó tagállamba, hogy ott egészségügyi szolgáltatást vegyen igénybe.

14 A tervezett egészségügyi ellátások adminisztrációjáról lásd bővebben Kristó Katalin - Malustyik Brigitta: A tervezett külföldi gyógykezelés engedélyezése Magyarországon: Az elektronikus ügyintézés egy lehetséges útja. Új Magyar Közigazgatás, 14. (2021), 2. 15-25.

15 Orvosilag szükségesnek az a természetbeni ellátás tekinthető, amelyet a tartózkodási hely szerinti tagállamban, annak jogszabályai alapján nyújtanak annak érdekében, hogy a biztosított a szükséges gyógykezelés céljából ne kényszerüljön tartózkodásának vége előtt visszatérni az illetékes tagállamba [Végrehajtási rendelet 25. cikk (3) bek.]. 
igénybevételéhez Európai Egészségbiztosítási Kártyával kell rendelkezni, amelyet a biztosítás helye szerinti egészégbiztosítási igazgatási szerv állít ki. Az ellátás költségeinek megtérítését a tagállami biztosító szervek egymás között rendezik (intézmények közti megtérítés). Fontos hangsúlyozni, hogy az EU-kártya birtokában a biztosított ugyanazon feltételek mellett jogosult az ellátásokra, mint amelyek a tartózkodási hely szerinti tagállam joga szerint biztosítottakra vonatkoznak. ${ }^{16}$

Magyarországon az EU-kártyát az ügyfelek személyesen, meghatalmazott útján, írásban, postai úton, vagy akár ügyfélkapun keresztül is igényelhetnek bármely, az egészségbiztosítási pénztári feladatkörben eljáró kormányhivataltól vagy kormányablaktól. Amennyiben az EU-kártyára irányuló kérelmet benyújtják, és az öszszes szükséges okmány rendelkezésre áll, valamint a kérelmező személy biztosítási jogviszonya, egészségügyi szolgáltatásra való jogosultsága egyértelmủen megállapítható a nyilvántartási rendszerből, úgy az ügyintéző megállapítja az EU-kártya kiadhatóságát és annak érvényességi időtartamát, és kiállítja az EU-kártyát a HYDRA rendszer segítségével.

Az eljárás - a jogosultsági feltételek fennállása esetén - a kiadott EU-kártya, vagy Kártyahelyettesítő nyomtatvány ${ }^{17}$ kiállításával zárul. Az EU-kártya kiadása térítésmentes, kivéve azon eseteket, ha megsemmisül, megrongálódik, elvész vagy ellopják. Ilyen esetekben igazgatási szolgáltatási díj fizetendő.

\subsection{Egészségügyi ellátásra való jogosultság másik tagállamban fennálló lakóhely esetén}

A koordinációs rendeleteknek köszönhetően az uniós polgárok az egyik tagállamból a másik tagállamba történő költözéskor nem veszítik el a korábbi lakóhelyük szerinti tagállamban megszerzett szociális jogaikat. A Rendelet 17. cikke értelmében amenynyiben a biztosított személy a munkavégzés helye szerinti tagállamtól eltérő tagállamban rendelkezik lakóhellyel, akkor a lakóhely szerinti tagállamban is részesülhet természetbeni ellátásokban, az illetékes intézmény által kiállított megfelelő nyomtatvány nyilvántartásba vételét követően (S1 nyomtatvány). A Rendelet 18. cikke pedig ezt a lehetőséget a biztosított családtagjaira is kiterjeszti.

Az Európai Unió tagállamaiban megszerzett jogosultságok igazolását, az egészségügyi szolgáltatáshoz való jog alátámasztását az Igazgatási Bizottság ${ }^{18}$ által kidolgozott, minden tagállam saját nyelvén kitölthető, egységes formanyomtatványok bevezetése tette lehetővé, amelynek egyik fajtája az E 100-as nyomtatványcsalád. A 2010. május 1. napján hatályba lépő Rendelettel új nyomtatványokat, úgynevezett strukturált

16 Végrehajtási rendelet 25. cikk (2) bek.

17 A Kártyahelyettesítő nyomtatvány kiadásának leggyakoribb esete, amikor egy korábbi egészségügyi ellátás igénybevétele miatt - visszamenőlegesen - kéri a biztosított, egy külföldi társadalombiztosítási intézmény vagy egészségügyi szolgáltató, vagy éppen ellenkezőleg: a jövőre vonatkozóan igénylik meg azt, amikor a biztosított már külföldön tartózkodik.

18 Az Igazgatási Bizottság az Európai Közösségek Bizottsága mellett működő, a szociális biztonsági rendszerek koordinációjával foglalkozó bizottság [Rendeletet 71. cikk (1) bek.]. 
elektronikus dokumentumokat ${ }^{19}$ (SED) vezettek be az E 100-as formanyomtatványok helyett, azok további alkalmazása mellett.

Magyarországon a kötelező egészségbiztosítás ellátásairól szóló 1997. évi LXXXIII. törvény $80 . \$(5)$ bekezdése ${ }^{20}$ szerint a külföldön létrejött jogviszonyt be kell jelenteni az egészségpénztári feladatkörében eljáró, lakóhely szerint illetékes kormányhivatalnak, amely a külföldi biztosítási jogviszonnyal rendelkező személy társadalombiztosítási azonosító jelét (taj) a bejelentés alapján átmenetileg érvényteleníteni fogja. Az érintett személy így abban a tagállamban lesz jogosult igénybe venni az egészségügyi ellátásokat, amelyben biztosítási jogviszonnyal rendelkezik. Amennyiben azonban a külföldön biztosított személy jogosult a fentiekben említett SED kiállítására, úgy annak bejegyzése után a tajszámot a lakóhely szerinti tagállamban újra érvényesítik. Ennek következtében az érintett személy a lakóhely szerinti tagállamban ismét jogosulttá válik az államilag finanszírozott természetbeni ellátások igénybevételére, azzal a különbséggel, hogy ezen ellátásokat már a külföldi biztosítása terhére veheti igénybe.

\subsection{Tervezett egészségügyi ellátás igénybevétele}

A tervezett egészségügyi ellátások igényérvényesítésének szabályait a koordinációs rendeletek, továbbá a határon átnyúló egészségügyi ellátásra vonatkozó betegjogok érvényesítéséről szóló 2011/24/EU irányelv tartalmazzák. E rendelkezéseknek az átültetésére a külföldön történő gyógykezelések részletes szabályairól szóló 340/2013. (IX. 25.) Korm. rendelet (Kormányrendelet) útján került sor a magyar jogrendszerben, amely a külföldön igénybe vett egészségügyi szolgáltatások részletes rendelkezéseit és hazai eljárásrendjét állapítja meg. E szabályozásoknak megfelelően külföldi egészségügyi szolgáltatás igénybevételére háromféle módon van lehetőség: uniós rendeletek alapján (rendeleti út), határon átnyúló egészségügyi ellátás keretében (irányelvi út), valamint méltányosságból (méltányossági út). Valamennyi esetben közös szabály, hogy az ellátás iránti igény elbírálása kérelemre indul, az elbírálás hatósági eljárás keretében történik, az ellátás indokoltságát független szakértő állapítja meg, és az eljárás teljes időtartama alatt a kérelmezőnek magyar társadalombiztosítási jogviszonnyal kell rendelkeznie. ${ }^{21}$ Mind a rendeleti, mind pedig a méltányossági út

19 Egy ügyviteli, illetve kommunikációs lépés végrehajtásához szükséges információkat tartalmazó űrlap, amelyből több is követheti egymást, az ügyben meghatározott ügyviteli folyamat rendje szerint. EESSI-ügyekben adategyeztetést szolgál az adatlap feladója és címzettje(i) között.

20 Az a tajszámmal rendelkező személy, aki

a) valamely EGT-tagállamban, illetve Svájcban, valamint a Magyarország által kötött nemzetközi egyezmény hatálya alá tartozó államban biztosított, vagy

b) a Tbj. 17. $\mathbb{S}(1)$ bek. a) pontja hatálya alá tartozó magyar állampolgár,

köteles a külföldön, illetve a nemzetközi szervezet szociális biztonsági rendszerében létrejött biztosítását és annak megszűnését 15 napon belül bejelenteni az egészségbiztosítónak.

21 A Nemzeti Egészségbiztosítási Alapkezelő hivatalos weboldala. 
esetében az ellátás igénybevétele előzetes engedélyhez kötött; az irányelvi út esetén a jogszabályban külön meghatározott ellátások engedélykötelesek.

\subsubsection{A rendeleti út}

Ennek értelmében a tervezett egészségügyi szolgáltatás igénybevétele iránti kérelmet a Nemzeti Egészségbiztosítási Alapkezelőhöz (NEAK) szükséges benyújtani, amely elsőként azt fogja vizsgálni, hogy az igénybe venni kívánt ellátás a magyar társadalombiztosításba befogadott-e. Amennyiben így van, a NEAK a következőkben azt fogja vizsgálni, hogy a beteget a kérelemben megjelölt orvosilag indokolt határidőn belül el tudja-e látni egy magyar egészségügyi szolgáltató. Ha a kezelést magyar egészségügyi szolgáltató is el tudja látni az orvosilag indokolt határidőn belül, akkor a NEAK elutasítja a kérelmet és javaslatot tesz egy magyar egészségügyi szolgáltatóra. ${ }^{22}$ Azonban, ha a biztosítás helye szerinti tagállam valamely egészségügyi szolgáltatója nem tudja ellátni az orvosilag meghatározott indokolt határidőn belül, a NEAK megvizsgálja a kérelemben megjelölt külföldi szolgáltató által nyújtott ellátás minőségét és biztonságát, valamint figyelembe veszi a költséghatékonysági szempontokat is. Költséghatékonynak akkor tekint egy ellátást, ha annak költsége nem haladja meg több mint 30\%-kal az ellátásra vonatkozó magyarországi belföldi költség mértékét. Ha a kérelemben megjelölt egészségügyi szolgáltató által nyújtott ellátás minőségével és biztonságával kapcsolatban nem merülnek fel aggályok, és az ellátás költséghatékonysági szempontból is megfelel a Kormányrendeletben foglaltaknak, akkor a NEAK tájékozódik az intézmény fogadókészségéről és a gyógykezelés lehetséges időpontjáról.

Abban az esetben, ha a megjelölt egészségügyi szolgáltató által nyújtott ellátásról megállapítást nyer, hogy nem elég biztonságos, a minősége nem megfelelő, vagy a költséghatékonysági szempontoknak nem felel meg, akkor a NEAK a megállapítástól számított nyolc napon belül kiadja az uniós rendeletek szerinti jogosultságigazolást és abban javaslatot tesz egy másik, EGT-tagállamban vagy Svájcban letelepedett egészségügyi szolgáltatóra. Az ilyen külföldi gyógykezelések költségeinek megtérítésére az uniós rendeletek szabályai szerint kerül sor, azzal a kitétellel, hogy a NEAK a külföldi gyógykezelés kötelezően meg nem térítendő részét (például az utazás költségét, vagy a kísérő költségeit) a beteg kérelmére méltányosságból támogathatja. ${ }^{23}$

\subsubsection{Az irányelvi út}

A határon átnyúló egészségügyi ellátásra vonatkozó betegjogok érvényesítéséről rendelkező, az Európai Parlament és a Tanács 2011/24/EU irányelve (Irányelv) elfogadásával az uniós jogalkotó olyan továbbfejlesztési javaslatokat fogalmazott meg, amelyek az előzőekben bemutatott eljárásrenden és feltételeken túl, egyéb esetekben is lehető-

22 Kormányrendelet 5. $\$(1)-(3)$ bek.

23 Kormányrendelet $5 . \mathbb{\$}(4)-(7)$ bek. 
vé teszik a külföldi egészségügyi szolgáltatásban való részesülést. A Kormányrendelet 3. része határozza meg az erre vonatkozó szabályokat, amelyek akkor lépnek életbe, ha a beteg olyan szolgáltatónál kíván külföldi gyógykezelést igénybe venni, ami nem tartozik az uniós rendeletek hatálya alá, vagy nem az uniós rendeletek szabályai szerint szeretné azt igénybe venni, vagy kérelmében az egészségügyi szolgáltató megjelölése nélkül, csak az egészségügyi szolgáltatásra kéri az engedélyt. Az irányelvi eljárás valósul meg akkor is, ha a külföldi gyógykezelésre jogosult személy által választott szolgáltatót a NEAK költséghatékonysági okból nem tartja elfogadhatónak és más szolgáltatóra tesz javaslatot, a beteg azonban a külföldi gyógykezelést nem az engedélyben szereplő, hanem az Európai Unió más tagállamában letelepedett egészségügyi szolgáltatónál veszi igénybe.

Ebben az esetben a NEAK ugyanazt az eljárást folytatja le, mint az előzőekben kifejtett uniós rendeletek szerinti gyógykezelés esetén, és a feltételeknek megfelelő kérelmet csak abban az esetben utasítja el, ha az ellátás orvosilag indokolt időn belül a hazai egészségügyi szolgáltatónál is biztosítható. Amennyiben a kérelemben megjelölt egészségügyi szolgáltató nem felel meg a Kormányrendeletben előírt költséghatékonysági feltételeknek, a NEAK más szolgáltatóra tehet javaslatot, de a beteg dönthet úgy, hogy nem a javasolt egészségügyi szolgáltatónál veszi igénybe az ellátást. ${ }^{24} \mathrm{~A}$ rendeleti úton történő engedélyezési eljárástól több szempontból is különbözik ez a metódus: ebben az esetben a betegnek lehetősége van magán egészségügyi szolgáltatónál igénybe venni az ellátást, továbbá az irányelvi ág esetén a betegnek meg kell előlegeznie a szolgáltatás költségeit, azok megtérítésére csak utólagosan van lehetőség. Az Irányelv tehát nem tartalmaz rendelkezéseket a tagállamok közötti elszámolásra, tekintettel arra, hogy a tagállami teherviselők ebben a rendszerben nincsenek egymással kapcsolatban, mivel a beteg kerül először kapcsolatba az ellátást nyújtó egészségügyi szolgáltatóval, majd - a számla benyújtása révén - később kapcsolatba lép a saját biztosítójával. ${ }^{25}$ Ennek következtében az elszámolás tekintetében nem uniós, hanem nemzeti eljárási szabályok vannak, amelyek a megtérítést belföldi hatókörrel szabályozzák. ${ }^{26}$ A Kormányrendelet értelmében a fizetendő térítés összege nem ha-

24 Kormányrendelet 7. $\$(1)-(2)$ bek.

25 Világos tehát - és a fentiekben már utaltunk is rá -, hogy az egészségügyi ellátás igénybevétele tipikusan közjogi szabályozásra épül (hatósági eljárás - kérelem, szakértői vizsgálat, engedélyezés stb.), a magán egészségügyi szolgáltató igénybevételekor azonban nyilvánvalóan már a polgári (kötelmi) jogi jogviszony kerül előtérbe, amelyről bővebben lásd Méhes Tamás: A Polgári Törvénykönyv vázlata. Budapest, Nemzeti Közszolgálati Egyetem, 2018. 111-140.

A tagállamok közötti kapcsolatrendszer és annak tárgya, a(z egészségügyi) szolgáltatás, illetve a szolgáltatás megfelelő (vagy éppen nem megfelelő) minősége és teljesítése, de leginkább a betegjogok érvényesítése szintén felvethet magánjogi kérdéseket, de a tagállami hatóság és a beteg között a hatósági jogviszonyra jellemző alá-fölé rendeltség természetesen egyértelmű. (Ellentétben például a hazai szabályozású jegyzői birtokvédelemmel, amelynek közigazgatási hatósági, vagy polgári jogi jellegét illetően a szakirodalom - meglepő módon - eltérő áláspontokat képvisel. Lásd Domokos Klaudia - Méhes Tamás: A (jegyzői) birtokvédelem és annak komplex jogi természete. Pro Publico Bono, 7. (2019), 3. 142-167.

26 Gellérné (2020): i. m. 1368-1369. 
ladhatja meg az igénybevétel idején az ellátásra vonatkozó magyarországi közfinanszírozott ellátás belföldi költségének mértékét. ${ }^{27}$

Az irányelvi szabályozással a jogalkotó célja olyan szabályok létrehozása volt, amelyek az Unióban megkönnyítik a határon átnyúló egészségügyi ellátáshoz való hozzáférést és biztosítják a betegmobilitást, ugyanakkor az Irányelv nem jogosít fel senkit arra, hogy egészségügyi ellátás igénybevétele céljából utazzon be, tartózkodjon vagy lakóhellyel rendelkezzen valamely tagállamban..$^{28}$

\subsubsection{A méltányossági út}

A tervezett külföldi egészségügyi ellátások szabályozásában a harmadik eljárási mód a méltányossági alapon történő igénybevétel. Erre abban az esetben kerül sor, ha a kérelem olyan ellátás igénybevételére irányul, amely Magyarországon a társadalombiztosításba nem befogadott. Ekkor a NEAK az egészségügyi dokumentációt továbbítja az Egészségügyi Szakmai Kollégium ügyben illetékes tagozata (Tagozat) részére. A Tagozat megvizsgálja a kezelés orvosszakmai indokoltságát, és megállapítja, hogy az ellátás szakmailag elfogadott-e és reális egészségnyereséggel jár-e. Az ellátás abban az esetben jár reális egészségnyereséggel, ha a beteg egészségi állapotának javulását vagy romlásának csökkenését eredményezi. A bírálat során figyelembe veszi a külföldi gyógykezelésekre jogosult személy egészségi állapotát és a betegségének várható lefolyását. Ha a Tagozat azt állapítja meg, hogy az ellátás nem jár reális egészségnyereséggel, vagy az ellátás szakmailag nem elfogadott, akkor a NEAK elutasítja a külföldi gyógykezelés iránti kérelmet. ${ }^{29}$ Amennyiben a Tagozat szakmailag elfogadottnak tartja az ellátást és megállapítja, hogy az a beteg számára reális egészségnyereséggel jár, akkor megvizsgálja, hogy a gyógykezelés elvégezhető-e külföldi szakember meghívásos közreműködésével az orvosi szempontból elfogadható határidőn belül, figyelembe véve a beteg egészségi állapotát és betegségének várható lefolyását. Viszont, amennyiben a Tagozat a külföldi gyógykezelés igénybevételét látja szükségesnek, javaslatot tesz külföldi egészségügyi szolgáltatóra, figyelembe véve a kérelemben feltüntetett egészségügyi szolgáltatót is. A Kormányrendeletben meghatározott esetekben ${ }^{30}$ a Tagozat javasolhat az Európai Unión, az EGT-n vagy Svájcon kívüli egészségügyi szolgáltatót is. ${ }^{31}$

A NEAK a Tagozat szakvéleményének beérkezése után dönt a külföldi gyógykezelés engedélyezéséről és a finanszírozás mértékéről. Amennyiben a NEAK nem ért egyet a Tagozat szakmai véleményével, azt megküldheti felülvizsgálat céljából

27 Kormányrendelet 7. \$ (3) bek.

28 Irányelv (10) és (18) bek.

29 Kormányrendelet $9 . \$(1)-(4)$ bek.

30 A Tagozat kizárólag abban az esetben tehet javaslatot az Európai Gazdasági Térségen és Svájcon kívül letelepedett egészségügyi szolgáltatóra, ha az ellátás az EGT tagállamaiban és Svájcban nem érhető el, vagy így a költségek hatékonyabb felhasználását eredményezi, vagy reális egészségnyereség-többletet eredményez.

31 Kormányrendelet 9. $\$(5)$ bek. 
az Egészségügyi Szakmai Kollégium elnökségének, aki vagy új javaslatot készít, vagy nyilatkozik arról, hogy a Tagozat véleményével egyetért. ${ }^{32}$

Bármely, a fentiekben ismertetett eljárás keretében került is sor a külföldi ellátás igénybevételére, az ellátást követő 30 napon belül a betegnek be kell mutatnia a keletkezett egészségügyi dokumentumokat, valamint a Kormányrendeletben előírt elszámolást. Az engedélyezett külföldi gyógykezeléshez kapcsolódóan a beavatkozást követő egy éven belül egy alkalommal előzetes engedély nélkül van lehetőség kontrollvizsgálat igénybevételére. További kontrollvizsgálatok igénybevételéhez külön engedélyezési eljárás lefolytatása szükséges, amely kizárólag akkor engedélyezhető, ha a kontrollvizsgálatoknak magyar közfinanszírozott egészségügyi szolgáltatónál nincsenek meg a feltételei. ${ }^{33}$

\subsection{A brexit következményei az egészségügyi ellátásokra való jogosultság tekintetében}

A brexitnek köszönhetően 2021. január 1. napjától az Egyesült Királyságban már nem alkalmazandók a koordinációs rendeletek. Jelenleg a Nagy-Britannia és ÉszakÍrország Egyesült Királyságának az Európai Unióból és az Európai Atomenergia Közösségből történő kilépéséről szóló Megállapodás (Kilépési Megállapodás), továbbá az Európai Unió és az Európai Atomenergia Közösségből, valamint Nagy-Britannia és Észak- Îrország Egyesült Királysága között kötött Kereskedelmi és Együttműködési Megállapodás (Kereskedelmi és Együttműködési Megállapodás), továbbá ez utóbbi Szociális biztonsági koordinációról szóló jegyzőkönyve (Jegyzőkönyv) tartalmazza az egészségügyi ellátások igénybevételével kapcsolatos szabályozást. ${ }^{34}$

A brit biztosítással rendelkező személyek magyarországi tartózkodásuk idején a brit biztosító által kiállított jogosultságigazolás birtokában (S1 dokumentum és EUkártya, illetve GHIC - Global Health Insurance Card) jogosultak ellátásra. A brit biztosító által 2021. január 1-je előtt kiállított EU-kártya az érvényességi idejének lejártáig jogosít a természetbeni ellátások igénybevételére, míg ezt követően GHIC-kártyát állítanak ki a biztosított részére a Jegyzőkönyvben meghatározott feltételekkel. Az S1, valamint a tervezett külföldi gyógykezelés igénybevétele céljából szükséges S2 dokumentumok használatának szabályai továbbra is alkalmazandók brit biztosítással rendelkezők esetén is.

A magyar egészségbiztosítással rendelkező személy részére, magyar intézmény által kiállított EU-kártya az Egyesült Királyságban továbbra is változatlan feltételekkel használható, valamint az Egyesült Királyságban lakóhellyel rendelkező magyar biztosított részére az $\mathrm{S} 1$ dokumentum továbbra is kiállítható.

32 Kormányrendelet 9. $\$(6)-(7)$ bek.

33 Kormányrendelet 10. \$.

34 A témáról lásd bővebben Gellérné Lukács Éva: Pillanatkép a Brexit munkaerőpiaci vonatkozásairól. Munkaügyi Szemle Online, 62. (2019), 4. 


\section{Fejlesztési lehetőségek a külföldi ellátások adminisztrációjában}

Napjaink technológiai fejlődését a közigazgatásnak is szükségszerűen követnie kell, fel kell vennie a versenyt a folyamatosan változó világgal. A változásokkal együtt járnak az állam működésével szemben támasztott új típusú elvárások is, azonban nemcsak a tagállamok közigazgatásának, hanem az Európai Uniónak is reagálnia kell a kihívásokra. ${ }^{35}$

A közigazgatási ügyintézési folyamatok elektronikussá tétele mára az ügyfélbarát közigazgatás egyik alapvető követelményévé vált. Az elektronikus ügyintézési lehetöségek valamennyi társadalmi szereplő számára közvetlenebb hozzáférést biztosítanak a szolgáltatásokhoz, javítva ezzel a szolgáltatások minőségét, valamint hatékonyabbá téve az állami szervek müködését. ${ }^{36} \mathrm{Az}$ elektronikus közigazgatási rendszerek folyamatos fejlesztése garantálja, hogy a hatósági eljárások során eddig kialakított gyakorlat az új kihívásoknak, az ügyfélorientált szemléletmódnak eleget tudjon tenni. ${ }^{37}$ A konkrét eljárások során fontos célkitűzéssé vált, hogy a közigazgatás digitalizálása a határokon átnyúló szolgáltatásokra is kiterjedjen, amelyre a belső piac négy alapvető szabadságának élénkítése érdekében van a leginkább szükség. Az Unió polgárai egész Európában elvárják, hogy a sajátjukon kívül más tagállamokban is részesüljenek a digitális technológia kínálta előnyökből. Emiatt is nagy jelentősége volt az EESSI informatikai rendszer, illetve ezzel összefüggésben Magyarországon a HYDRA szakalkalmazás bevezetésének, amelyek segítségével a tagállamok intézményei és összekötő szervei gyorsabban és hatékonyabban tudnak egymással kommunikálni.

Fontos ugyanakkor kiemelni, hogy az EESSI-rendszer és a strukturált elektronikus dokumentumok csak a tagállami szervek közötti kommunikációra szolgálnak, az ügyfelek rendszerbe történő becsatornázása még nem történt meg. Így az ügyfelek sok esetben hordozható dokumentumok formájában tartják maguknál az információkat, amelyek egy része az ügyfél számára, másik része pedig a szociális biztonsági szerv számára tartalmaz információkat. ${ }^{38} \mathrm{E}$ tekintetben számottevő előrelépés lenne egyfajta elektronikus ügyintézési metódus kialakítása, amely az EESSI-rendszer kiegé-

35 Czékmann Zsolt: Információs társadalom és elektronikus kormányzat Magyarországon. Miskolci Egyetem, Állam- és Jogtudományi Kar, Deák Ferenc Állam- és Jogtudományi Doktori Iskola, Miskolc, 2016.

36 Csáki-Hatalovics Gyula Balázs - Czékmann Zsolt: Az elektronikus közigazgatás fogalma. In Czékmann Zsolt (szerk.): Infokommunikációs jog. Budapest, Dialóg Campus, 2019. 21.

37 Patyi András ugyanakkor felhívja a figyelmet arra, hogy „Az emberi magatartás, a közigazgatás nevében és jogalanyiságán belül cselekvő tisztviselő magatartása, mint egyedüli jogi tény megítélését relativizálja, vagy akár meg is változtatja a közigazgatási feladatellátás és hatáskörgyakorlás digitalizációja vagy elektronizálása." Patyi András: A közigazgatási müködés jogi alapjai. Budapest, Dialóg Campus, 2017. 195.

38 Fürjes Annamária: A szociális biztonsági rendszerek koordinációja az Unióban - különös tekintettel a nyugdijakra. Szeged, Szegedi Tudományegyetem Állam- és Jogtudományi Kar Doktori Iskola, 2014. 150 . 
szítéseként müködve támogatná az ügyfelek és a szociális biztonsági szervek közötti pontosabb és hatékonyabb kommunikációt. ${ }^{39}$

Az egészségügyi ellátások más uniós tagállamban történő igénybevételéhez kapcsolódóan fontos lenne az intelligens kártyák olyan új generációjának bevezetése, amellyel a beteg egészségügyi ellátási adataihoz való egyszerű hozzáférést lehetne biztosítani. Az új kártyák alkalmazásával egyszerűsödne az orvosi ellátás igénybevétele az Európai Unió minden tagállamában. Mindez azt jelentené, hogy külföldi tartózkodás során az orvosilag szükséges ellátás igénybevételekor az EU-kártyával az ellátást nyújtó orvos hozzáférne a kórtörténeti dokumentációhoz, így biztonsággal választhatna a helyes terápia alkalmazásának tárgyában. E rendszert továbbfejlesztve létre kellene hozni egy olyan elektronikus felületet, amelyen a beteg biztosítójánál történő lekérdezést követően arra is választ kaphatna az orvos, hogy az adott beteg jogszerủen veszi-e igénybe az ellátást, vagyis rendelkezik-e ténylegesen biztosítási jogviszonnyal, vagy egészségügyi szolgáltatásra való jogosultsággal az ellátás igénybevételének időpontjában.

\section{Irodalomjegyzék}

Czékmann Zsolt: Információs társadalom és elektronikus kormányzat Magyarországon. Miskolc, Miskolci Egyetem, Állam- és Jogtudományi Kar, Deák Ferenc Állam- és Jogtudományi Doktori Iskola, 2016. Online: https://doi.org/10.14750/ME.2016.027

Csáki-Hatalovics Gyula Balázs - Czékmann Zsolt: Az elektronikus közigazgatás fogalma. In Czékmann Zsolt (szerk.): Infokommunikációs jog. Budapest, Dialóg Campus, 2019.

Domokos Klaudia - Méhes Tamás: A (jegyzői) birtokvédelem és annak komplex jogi természete. Pro Publico Bono, 7. (2019), 3. 142-167. Online: https://doi.org/10.32575/ppb.2019.3.8

Fürjes Annamária: A szociális biztonsági rendszerek koordinációja az Unióban - különös tekintettel a nyugdijakra. Szeged, Szegedi Tudományegyetem, Állam- és Jogtudományi Kar Doktori Iskola, 2014. Online: http://doktori.bibl.u-szeged.hu/id/eprint/2417/1/Furjes_Annamaria_ertekezes.PDF

Gellérné Lukács Éva: Pillanatkép a Brexit munkaerőpiaci vonatkozásairól. Munkaügyi Szemle Online, 62. (2019), 4. Online: https://drive.google.com/file/d/1yZ0nmYTruCqCLvJGE2mvjdnbWE Fenrvr/view

Gellérné Lukács Éva: Egészségügyi szolgáltatások igénybevétele. In Smuk Péter (szerk.): Társadalmi fenntarthatóság. Budapest, Ludovika Egyetemi Kiadó, 2020.

Hajdú József: A szociális jog elmúlt 20 évéről, különös tekintettel az Európai Unióra. In Miskolczi Bodnár Péter- Kun Attila - Boóc Ádám (szerk.): Gazdaság és jog. Húsz év jogalkotási fejleményei a civilisztika területén. Budapest, Károli Gáspár Református Egyetem Állam- és Jogtudományi Kar. 2019. 11-28.

Kristó Katalin: Szociálpolitika, szociális jog. Budapest, Nemzeti Közszolgálati Egyetem, 2014.

Kristó Katalin - Malustyik Brigitta: A tervezett külföldi gyógykezelés engedélyezése Magyarországon:

Az elektronikus ügyintézés egy lehetséges útja. Új Magyar Közigazgatás, 14. (2021), 2. 15-25.

Méhes Tamás: A Polgári Törvénykönyv vázlata. Budapest, Nemzeti Közszolgálati Egyetem, 2018. Patyi András: A közigazgatási müködés jogi alapjai. Budapest, Dialóg Campus, 2017.

39 Egy ilyen elektronikus ügyintézési szisztéma kialakítására tesz javaslatot Kristó Katalin és Malustyik Brigitta közös tanulmányukban, lásd Kristó-Malustyik (2021): i. m. 15-25. 


\section{Jogforrások}

Az Európai Parlament és a Tanács 883/2004/EK rendelete a szociális biztonsági rendszerek koordinálásáról

Az Európai Parlament és a Tanács 987/2009/EK rendelete a szociális biztonsági rendszerek koordinálásáról szóló 883/2004/EK rendelet végrehajtására vonatkozó eljárás megállapításáról

Az Európai Parlament és a Tanács 2011/24/EU irányelve a határon átnyúló egészségügyi ellátásra vonatkozó betegjogok érvényesítéséről

1997. évi LXXXIII. törvény a kötelező egészségbiztosítás ellátásairól

340/2013. (IX. 25.) Korm. rendelet a külföldön történő gyógykezelések részletes szabályairól

\section{Internetes forrás}

Nemzeti Egészségbiztosítási Alapkezelő: Ellátás külföldön. Online: www.neak.gov.hu/felso_menu/ lakossagnak/ellatas_kulfoldon 